He had come to think that the critical problems of government arose not so much from technical difficulties of policy and administration as from underlying political institutions seemingly incapable of offering clear alternatives and mustering coherent majorities in support of reasonable policy choices. In that concern, he joined a group that became the American Political Science Association's Committee on Political Parties; its recommendations, Toward a More Responsible Two-party System (1950) touched off scholarly debate about the ideal and actual nature of political parties that continues to this day. Party competition and its implication for policy would become a recurring theme in Paul's later work.

In 1950, Paul returned to Brookings and began a decade of research on political parties. He organized a complex joint project of Brookings and APSA to study the presidential nominations of 1952 , nationwide, from grass roots caucuses through the party conventions. The product was five volumes on Presidential Nominating Politics in 1952 (1954), by David, Malcolm Moos, and Ralph M. Goldman, plus 70 contributors of data from their respective states. Later came another important book, The Politics of National Party Conventions (1960), by David, Goldman, and R. C. Bain. Those two studies made Paul the leading scholarly expert on nominating processes, conventions, and party governance during the ensuing period of rapid reform of those institutions; he became a frequent adviser to party activists and the media. At Brookings in the 1950s he also served as Director of Governmental Studies, 1955-58, and had a large hand in projects as varied as administration of foreign affairs, executive personnel systems, and presidential elections and transitions.

After a year at the Center for Advanced Study in the Behavioral Sciences at Stanford, Paul joined the faculty of the University of Virginia in 1960. His teaching area was American politics, particularly parties, elections, and the presidency. In research, he went straight to a critical issue of the time in a study, with Ralph Eisenberg, that produced for every U.S. county a statistical measure of the distortion of representation caused by the apportionment of state legislatures, still largely unreformed prior to Baker v. Carr. Devaluation of the Urban and Suburban Vote $(1961,1962)$ bolstered the case for reapportionment and became a handbook for reformers as the "one person-one vote" principle was implemented in the next few years. Paul later called it his most consequential single piece of work.

In the mid-1960s Paul served a term as department chairman at Virginia during a period of rapid growth and painful institutional change. Also in this time came his most ambitious intellectual endeavor, an experimental doctoral program built around a doublecredit course he developed on "Processes of Change: Origins, Interactions, and Governmental Consequences." This required assembly of an enormous range of materials from all the social sciences and beyond. Although survivors called the course a fantastic experience, the reading list was daunting, and both students and other faculty members had difficulty relating it to the conventional subfields of political science required for the Ph.D. exams. Processes of Change might have been a success in the context of adult general education but it could not survive in an environment emphasizing disciplinary specialization.

Paul returned to more familiar political science, but his research continued to have innovative thrusts. A 1967 article on the vice presidency called early attention to possibilities for invigorating that office, and a 1971 piece on "Party Platforms As National Plans" echoed his interest in connecting parties and policy. His last major research was an historical analysis of Party Strength in the U.S., 18721970 (1972), based on a measure of party competition he devised. Subsequent articles updated the application of what has become known as "David's Index of Party Strength," and the series is being continued by the Inter-University
Consortium on Political and Social Research.

After official retirement in 1977, Paul continued to produce occasional articles on party competition, nominations, and the "responsible parties" issue. He travelled widely, both for pleasure and to serve as visiting professor or lecturer at several institutions in the U.S. and abroad. He was an occasional seminar leader at the Federal Executive Institute and an active adviser to the Miller Center for Public Affairs in Charlottesville. A life member of APSA, he contributed lengthy interviews for the association's Oral History project.

Toward the end of his life, Paul was delighted to discover that his early work in civil aviation was known to historians of that subject. His last publication was a detailed memoir of the 1944 Chicago conference for a 50th anniversary commemorative volume; considering his years and declining health it was a remarkable feat of archival research, precise recollection, and clear writing. He would miss by a few months honors due to be rendered at international conferences celebrating anniversaries of Chicago and ICAO.

Paul is survived by his wife Opal, a fellow Antiochian whom he met and married in TVA days, a social force with many accomplishments in public administration, education for women, and local government in Albemarle County. They had no children but a host of friends and admirers of a remarkable team.

Ralph M. Goldman Catholic University Laurin L. Henry Kenneth W. Thompson University of Virginia

\section{Roger Wells}

Roger Hewes Wells, Ph.D., died at age 100 in Jacksonville, IL, on June 16, 1994. He was a Professor Emeritus and former Chairman of the Political Science Department at Bryn Mawr College, PA, where he taught for 40 years. Dr. Wells was noted for his contribution to the 
restoration of Germany as a democracy after World War II, when he was Deputy Director of Civil Administration in the U.S. Military Government from 1945-47.

An expert on German municipal administration, he was also instrumental in the drafting of the Bavarian Constitution. He was a member of the U.S. Delegation to the Moscow Conference of Foreign Ministers in 1947. For his work in Germany, he was awarded the U.S.

Medal of Freedom.

Dr. Wells returned to Germany in 1951-53 as Chief of the Historical Division of the U.S. High Commission and was the editor of numerous historical monographs. From 1953-55, he served as the director of a task force of the U.S. Commission on Intergovernmental Relations.

Born in Quincy, IL, the son of a well-known physician, Dr. Wells graduated in 1916 from Northwest- ern University, summa cum laude, with a major in history and was elected to Phi Beta Kappa. After a year as a civics teacher in Quincy High School, he enlisted in the 33rd Infantry Division during World War I, receiving a field commission in France. In 1920, he became a teaching fellow at Harvard University, where, three years later he received his $\mathrm{PhD}$ in government.

He was a panel chairman of the War Labor Board in World War II and is a former President of the Pennsylvania Political Science Association and the Philadelphia International Institute.

After his retirement from Bryn Mawr College, Dr. Wells returned to Illinois and served as a visiting professor of government at Mac Murray College from 1963-68. He remained active in civic affairs until his death and was a driving force in Central Illinois in the establishment of alcohol and drug rehabilitation programs. The Wells Center, serving 14 counties in Illinois, was named in his honor.

Among Dr. Wells's publications, three books stand out: German Cities: A Study of Contemporary Politics and Administration (1932); American Local Government (1939); and The States in West German Federalism: A Study in Federal-State Relations, 1949-60 (1961).

As one of the last surviving veterans of World War I, he was accorded full military honors at his interment by color guards of veterans' organizations and a unit of the 33rd Infantry Division (Illinois National Guard).

His wife, Stella Dueringer Wells, preceded him in death. He is survived by two daughters, Lois $\mathrm{E}$. Wells of Jacksonville, IL, and Elsa Wells Kormann of Chevy Chase, MD, three grandchildren, and seven great-grandchildren.

Elsa Wells Kormann 